\title{
PENGARUH PROFITABILITAS, LIKUIDITAS DAN UKURAN PERUSAHAAN TERHADAP KETEPATAN WAKTU PENYAMPAIAN LAPORAN KEUANGAN (STUDI EMPIRIS PADA PERUSAHAAN MANUFAKTUR SEKTOR INDUSTRI BARANG KONSUMSI YANG TERDAFTAR DI BURSA EFEK INDONESIA PERIODE 2010-2014)
}

\author{
Kartika Damayanti \\ kartikadama9@gmail.com \\ Universitas Ahmad Dahlan \\ Dyah Fitriani \\ dhifa_dhe@yahoo.com \\ Universitas Ahmad Dahlan
}

\begin{abstract}
ABSTRAK
Timeliness of the submission of Go's financial statements public is important for disclosing accounting information used by market participants in the investment decisionmaking process. This study aims to find empirical evidence about the factors that are affect the timeliness of financial reporting of manufacturing sector companies the consumer goods industry which is listed on the Indonesia Stock Exchange. Factors tested in this study are return on assets, current ratio, and total assets. The population in this study is the Industrial Sector Manufacturing Company Consumer goods a total of 40 companies are then taken as many samples 28 companies use purposive sampling techniques. Analytical techniques used logistic regression with a confidence level of $5 \%$. The results of the study shows that profitability has a significant effect on accuracy financial reporting time, whereas liquidity and company size are not significantly influence the timeliness of financial reporting.
\end{abstract}

Keywords: Timeliness; Return On Assets; Current Ratio; Total Assets.

\section{PENDAHULUAN}

Setiap perusahaan yang terdaftar di Bursa Efek Indonesia harus melaporkan keuangan perusahaannya tiap tahunnya. Laporan keuangan merupakan salah satu sumber informasi penting dalam bisnis investasi di pasar modal yang disediakan setiap perusahaan yang Go Public. Pelaporan keuangan adalah laporan keuangan yang ditambah dengan informasi-informasi lain yang berhubungan, baik langsung maupun tidak langsung dengan informasi yang disediakan oleh sistem akuntansi keuangan, seperti informasi tentang sumber daya perusahaan, earnings, current cost, informasi tentang prospek perusahaan yang merupakan bagian integral dengan tujuan untuk memenuhi tingkat pengungkapan yang cukup. (Yadiati, 2007)

Unsur utama dari pelaporan keuangan adalah laporan keuangan. Laporan keuangan menyediakan informasi keuangan suatu entitas yang bermanfaat bagi pihak-pihak yang berkepentingan untuk dasar pembuatan keputusan-keputusan ekonomi (Sutrisno, 2000). Di pasar modal, laporan keuangan perusahaan memiliki fungsi yang sangat strategis. Laporan keuangan merupakan informasi yang menggambarkan dan untuk menilai kinerja perusahaan, terlebih 
bagi perusahaan yang sahamnya telah tercatat dan diperdagangkan di Bursa Efek Indonesia. Informasi yang terdapat dalam laporan keuangan perusahaan dapat memberikan analisa laporan keuangan untuk menilai kinerja perusahaan yang juga mencerminkan fundamental perusahaan sehingga informasi tersebut dapat memberikan landasan bagi keputusan investasi. Perusahaan di Indonesia khususnya perusahaan yang sudah go public diharuskan untuk menyusun laporan keuangan setiap periodenya. Menurut Ikatan Akuntan Indonesia (2009) laporan keuangan mempunyai tujuan untuk memberikan informasi tentang posisi keuangan, kinerja, dan arus kas perusahaan yang bermanfaat bagi sebagian besar kalangan pengguna laporan dalam rangka membuat keputusan-keputusan ekonomi serta menunjukkan pertanggungjawaban (stewardship) manajemen atas penggunaan sumber-sumber daya yang dipercayakan kepada mereka. Oleh karena itu, laporan keuangan sebagai sebuah informasi akan bermanfaat apabila informasi yang dikandungnya disediakan tepat waktu bagi pembuat keputusan sebelum informasi tersebut kehilangan kemampuannya dalam mempengaruhi pengambilan keputusan.

Ketepatan waktu penyampaian laporan keuangan merupakan hal yang penting untuk mengungkapkan informasi. Pernyataan Standar Akuntansi Keuangan (PSAK) juga menyatakan bahwa manfaaat suatu laporan akan berkurang jika laporan tersebut tidak tersedia tepat waktu (PSAK No. 1 par. 38, 2009). Ketepatan waktu penyerahan laporan keuangan merupakan karakteristik yang penting bagi informasi akuntansi karena informasi yang telah lewat akan lebih sedikit digunakan oleh partisipan pasar dalam proses pembuatan keputusan investasi, karena informasi yang disampaikan tersebut kemungkinan sudah kehilangan nilai relevansinya.
Berdasarkan regulasi di Indonesia bahwa tepat waktu merupakan kewajiban bagi perusahaan terdaftar di Bursa Efek Indonesia (BEI) untuk menyampaikan laporan keuangan secara berkala. Tahun 1996, BAPEPAM mengeluarkan lampiran keputusan ketua BAPEPAM No.80/PM/1996, yang mewajibkan bagi setiap emiten dan perusahaan publik untuk menyampaikan laporan keuangan tahunan perusahaan dan laporan auditor independennya kepada BAPEPAM selambat-lambatnya 120 hari setelah tanggal laporan tahunan perusahaan. Namun sejak tanggal 30 September 2003, Bapepam semakin memperketat peraturan dengan dikeluarkannya Peraturan Bapepam Nomor X.K.2, Lampiran Keputusan Ketua Bapepam Nomor: KEP36/PM/2003 tentang Kewajiban Penyampaian Laporan Keuangan Berkala. Peraturan Bapepam Nomor X.K.2 ini menyatakan bahwa laporan keuangan tahunan harus disertai dengan laporan Akuntan dengan pendapat yang lazim dan disampaikan kepada Bapepam selambat-lambatnya pada akhir bulan ketiga (90 hari) setelah tanggal laporan keuangan tahunan. Peraturan Bapepam dan LK Nomor X.K.6 menyatakan bahwa dalam hal penyampaian laporan tahunan dimaksud melewati batas waktu penyampaian laporan keuangan tahunan sebagaimana diatur dalam Peraturan Bapepam Nomor X.K.2 tentang Kewajiban Penyampaian Laporan Keuangan Berkala, maka hal tersebut diperhitungkan sebagai keterlambatan penyampaian laporan keuangan tahunan.

Rasio profitabilitas merupakan rasio yang digunakan untuk mengukur kemampuan perusahaan dalam menghasilkan laba atau mengukur efektivitas manajemen dalam menghasilkan keuntungan dari penjualan dan investasi (Asakdiyah, 2006). Perusahaan dengan kondisi keuangan yang baik (good news) biasanya akan segera menerbitkan laporan keuangan untuk menarik perhatian investor, 
kreditor, pelanggan, dan pengguna lain. Perusahaan dengan kondisi laba lebih cenderung segera menerbitkan laporan keuangan secara tepat waktu untuk menggambarkan kondisi operasional perusahaan selama periode tersebut. Rasio profitabilitas dalam penelitian ini menggunakan rasio return on asset (ROA) sebagai alat ukur yaitu perbandingan antara laba bersih setelah bunga dan pajak dengan total assets.

Menurut James (2005) rasio likuiditas digunakan untuk mengukur kemampuan perusahaan untuk memenuhi kewajiban jangka pendeknya. Rasio ini membandingkan kewajiban jangka pendek dengan sumber daya jangka pendek (atau lancar) yang tersedia untuk memenuhi kewajiban tersebut. Dari rasio ini banyak pandangan ke dalam yang bisa didapatkan mengenai kompetensi keuangan saat ini perusahaan dan kemampuan perusahaan untuk tetap kompeten jika terjadi masalah. Salah satu dari rasio likuiditas yang paling umum dan sering digunakan adalah rasio lancar (current ratio).

Ukuran perusahaan adalah suatu skala dimana dapat diklasifikasikan besar kecilnya perusahaan menurut berbagai cara, yaitu: total assets, log size, nilai pasar saham dan lain-lain (Suwito, 2005). Ukuran perusahaan dalam penelitian ini diukur dari total assets yang dimiliki perusahaan. Total assets dipilih sebagai proksi dari variabel ukuran perusahaan. Hal ini dikarenakan total assets lebih stabil dan representatif dalam menunjukkan ukuran perusahan dibanding kapitalisasi pasar dan penjualan yang sangat dipengaruhi oleh demand and supply (Sudarmadji, 2007). Definisi dari total assets adalah segala sumber daya yang dikuasai oleh perusahaan sebagai akibat dari transaksi masa lalu dan diharapkan akan memberikan manfaat ekonomi bagi perusahaan di masa yang akan datang (Ikatan Akuntan Indonesia, 2009).
Melihat pentingnya ketepatan waktu dalam pelaporan keuangan menyebabkan banyak peneliti tertarik untuk menganalisis faktor-faktor yang mempengaruhi ketepatan waktu dalam pelaporan keuangan. Dari beberapa penelitian yang telah dilakukan, terdapat perbedaan pada hasil analisis antara penelitian yang satu dengan penelitian yang lain. Adanya perbedaan hasil dalam penelitian-penelitian sebelumnya yang telah dilakukan menarik penulis untuk menguji ulang faktor-faktor yang mempengaruhi ketepatan waktu dalam pelaporan keuangan dengan mengurangi ataupun menambah variable penelitian, menambah tahun pengamatan, serta perbedaan objek penelitian.

Tujuan dari penelitian ini di antaranya: 1) mengetahui pengaruh profitabilitas terhadap ketepatan waktu penyampaian laporan keuangan perusahaan manufaktur sektor industri barang konsumsi yang terdaftar di BEI, 2) mengetahui pengaruh likuiditas terhadap ketepatan waktu penyampaian laporan keuangan perusahaan manufaktur sektor industri barang konsumsi yang terdaftar di BEI dan 3) mengetahui pengaruh ukuran perusahaan terhadap ketepatan waktu penyampaian laporan keuangan perusahaan.

\section{REVIEW LITERATUR DAN HIPOTESIS}

\section{Landasan Teori}

1. Laporan Keuangan

Laporan

keuangan

menggambarkan kondisi keuangan dan hasil usaha suatu perusahaan pada saat tertentu atau jangka waktu tertentu. (Harahap, 2007).

2. Ketepatan Waktu Pelaporan Keuangan Ketepatan waktu penyampaian laporan keuangan merupakan hal yang penting untuk mengungkapkan informasi. Pernyataan Standar Akuntansi Keuangan (PSAK) juga 
menyatakan bahwa manfaaat suatu laporan akan berkurang jika laporan tersebut tidak tersedia tepat waktu (PSAK No. 1 par. 38, 2009). Ketepatan waktu penyerahan laporan keuangan merupakan karakteristik yang penting bagi informasi akuntansi karena informasi yang telah lewat akan lebih sedikit digunakan oleh partisipan pasar dalam proses pembuatan keputusan investasi, karena informasi yang disampaikan tersebut kemungkinan sudah kehilangan nilai relevansinya.

\section{Profitabilitas}

Rasio profitabilitas (profitability ratio) terdiri atas dua jenis rasio yang menunjukkan profitabilitas dalam kaitannya dengan penjualan dan rasio yang menunjukkan profitabilitas dalam kaitannya dengan investasi. Bersamasama, rasio-rasio ini akan menunjukkan efektivitas operasional keseluruhan perusahaan. Return on Asset (ROA) biasanya disebut sebagai hasil pengembalian atas total aktiva. Rasio ini mencoba mengukur efektivitas pemakaian total sumber daya oleh perusahaan. ROA yang digunakan diukur dengan membagi laba bersih (Net Income After Tax) dengan total aktiva (Average Total Assets), dapat dirumuskan sebagai berikut:

$$
\text { Return on Asset }=\frac{\text { Laba Bersih }}{\text { Total Aktiva }} \times 100
$$

Profitabilitas perusahaan yang tinggi menunjukkan bahwa kinerja manajemen perusahaan tersebut baik. Perusahaan yang memiliki profitabilitas tinggi dapat dikatakan bahwa laporan keuangan perusahaan tersebut mengandung berita baik dan perusahaan yang mengalami berita baik cenderung menyerahkan laporan keuangannya dengan tepat waktu (Hilmi, 2008).

\section{Likuiditas}

Rasio likuiditas (liquidity ratio) digunakan untuk mengukur kemampuan perusahaan untuk memenuhi kewajiban jangka pendeknya. Rasio ini membandingkan kewajiban jangka pendek dengan sumber daya jangka pendek (atau lancar) yang tersedia untuk memenuhi kewajiban tersebut. Rasio likuiditas menunjukkan hubungan kas dan aktiva lancar lainnya dengan kewajiban lancar. Posisi likuiditas perusahaan akan sangat berhubungan dengan kemampuan perusahaan melunasi kewajiban jangka pendeknya. Salah satu dari rasio likuiditas yang paling umum dan sering digunakan adalah rasio lancar (current ratio).

$$
\begin{array}{r}
\text { Current Ratio }=\frac{\text { Aktiva lancar }}{\text { Kewajiban jangka pendek }} \\
\text { William et al., (2008) dalam }
\end{array}
$$
Nasution (2009) menyatakan bahwa likuiditas juga merupakan perhatian utama para investor dan kreditur selain profitabilitas perusahaan. Perusahaan yang memiliki tingkat likuiditas yang tinggi cenderung memiliki kondisi keuangan yang baik karena dapat segera mencairkan assets (harta) yang tersedia untuk melunasi hutang (kewajiban) ketika jatuh tempo. Dengan adanya pandangan ini, maka perusahaan yang memiliki likuiditas yang tinggi akan cenderung tepat waktu dalam pelaporan keuangannya untuk menunjukan bahwa perusahaan dalam kondisi yang kredibel dan pencapaian kinerja manajemen yang efektif.

\section{Ukuran Perusahaan}

Semakin besar aset suatu perusahaan maka akan semakin besar pula modal yang ditanam, semakin besar total penjualan suatu perusahaan maka akan semakin banyak juga perputaran uang dan semakin besar kapitalisasi pasar maka semakin besar 
pula perusahaan dikenal oleh masyarakat (Hilmi, 2008).

Ukuran perusahaan menunjukkan seberapa besar informasi yang terkandung di dalam perusahaan tersebut dalam Hilmi (2008) dan Owusu (2000) dalam penelitian mereka menemukan bahwa ukuran perusahaan secara signifikan mempunyai hubungan dengan ketepatan waktu penyampaian laporan keuangan. Variabel yang mereka gunakan untuk menjelaskan ukuran perusahaan adalah total aset. Bukti empiris yang ada menunjukkan bahwa perusahaan yang memiliki aset yang lebih besar dapat melaporkan lebih cepat dibandingkan dengan perusahaan yang memiliki aset yang lebih kecil. Mereka berpendapat bahwa perusahaan yang memiliki sumber daya (aset) yang besar memiliki lebih banyak sumber informasi, lebih banyak staf akuntansi dan sistem informasi yang lebih canggih, memiliki sistem pengendalian intern yang kuat, adanya pengawasan dari investor, regulator dan sorotan masyarakat, hal ini memungkinkan perusahaan dengan ukuran yang besar dalam melaporkan laporan keuangan auditannya lebih cepat ke publik dibandingkan dengan perusahaan yang lebih kecil.

\section{Penelitian Terdahulu}

Permana (2009) denga judul "Pengaruh Profitabilitas, Leverage, Likuiditas dan Ukuran Perusahaan terhadap Ketepatan Waktu Penyampaian Laporan Keuangan Perusahaan Properti yang terdaftar di BEI". Hasil dari penelitian menunjukkan bahwa profitabilitas, leverage, likuiditas dan ukuran perusahaan tidak berpengaruh signifikan terhadap ketepatan waktu penyampaian laporan keuangan. Namun, apabila keempat variable diuji secara simultan maka berpengaruh signifikan terhadap ketepatan waktu penyampaian laporan keuangan.
Evi, dkk (2014) tentang "Pengaruh Profitabilitas dan Likuiditas terhadap Ketepatan Waktu Pelaporan Keuangan (Studi Empiris pada Perusahaan LQ45 yang terdaftar di BEI periode 20082012)", diperoleh kesimpulan bahwa profitabilitas dan likuiditas tidak berpengaruh signifikan terhadap ketepatan waktu pelaporan keuangan.

\section{Hipotesis}

$\mathrm{H1}$ : semakin tinggi profitabilitas maka semakin tinggi kemungkinan ketepatan waktu penyampaian laporan keuangan perusahaan manufaktur sektor industri barang konsumsi yang terdaftar di BEI.

$\mathrm{H} 2$ : semakin tinggi likuiditas maka semakin tinggi kemungkinan ketepatan waktu penyampaian laporan keuangan perusahaan manufaktur sektor industri barang konsumsi yang terdaftar di BEI.

H3: semakin besar ukuran perusahaan maka semakin besar kemungkinan ketepatan waktu penyampaian laporan keuangan perusahaan manufaktur sector industry barang konsumsi yang terdaftar di BEI.

\section{METODE PENELITIAN}

\section{Populasi dan Sampel}

Populasi dari penelitian ini adalah semua perusahaan manufaktur sektor industri barang konsumsi yang terdaftar di Bursa Efek Indonesia. Dari data yang diperoleh, tercatat sebanyak 40 perusahaan manufaktur sektor industri barang konsumsi yang terdaftar di Bursa Efek Indonesia.

Sampel pada penelitian ini adalah perusahaan manufaktur sektor industri barang konsumsi yang terdaftar di Bursa Efek Indonesia periode 2010-2014. Pengambilan sampel menggunakan teknik purposive sampling, yaitu teknik 
penentuan sampel dengan pertimbangan tertentu (Sugiyono, 2013). Adapun kriteria yang digunakan adalah sebagai berikut:

1. Termasuk perusahaan manufaktur sector industri barang konsumsiyang terdaftar di Bursa Efek Indonesia.

2. Sampel mempunyai periode pelaporan keuangan berdasarkan pada tahun kalender yang berakhir tanggal 31 Desember.

3. Menerbitkan laporan keuangan auditan yang dipublikasikan selama tahun 2010, 2011, 2012, 2013, 2014 secara berturutturut.

4. Perusahaan manufaktur sector industri barang konsumsi yang tidak keluar dari BEI selama periode penelitian.

Dari kriteria yang telah disebutkan di atas, maka diperoleh 28 perusahaan yang memenuhi kriteria untuk dijadikan sampel.

\section{Definisi Operasional}

1. Variabel Independen

a. Profitabilitas

Variabel ini dihitung dengan menggunakan Return On Assets (ROA). Rasio ini merupakan perbandingan dari laba bersih setelah bunga dan pajak dengan total aset.

$$
\text { Return on Asset }=\frac{\text { Laba Bersih }}{\text { Total Aktiva }} \times 100
$$

b. Likuiditas

Variabel ini dihitung dengan menggunakan Current Ratio (CR). Current Ratio (CR) merupakan perbandingan dari aset lancar dengan hutang lancar.

$$
\text { Current Ratio }=\frac{\text { Aktiva lancar }}{\text { Kewajiban jangka pendek }}
$$

c. Ukuran Perusahaan

Variabel ini merupakan variabel yang digunakan untuk mengukur seberapa besar atau kecilnya sampel perusahaan yang digunakan. Pada penelitian ini, ukuran perusahaan dapat dinilai berdasarkan Log Total Asset (TA) perusahaan dengan alasan untuk menghindari adanya data yang terdistribusi tidak normal jika ukuran perusahaan hanya dihitung dengan total asset.

Ukuran Perusahaan $=$ Log Total Aset

2. Variabel Dependen

Dalam penelitian ini, variabel yang menjadi variabel independen adalah ketepatan waktu pelaporan keuangan perusahaan manufaktur sektor industri barang konsumsi, yang selanjutnya diberi simbol "TL". Ketepatan waktu diukur melalui tanggal penyampaian pelaporan keuangan kepada Bapepam, jika laporan keuangan disampaikan selambat-lambatnya pada akhir bulan ketiga (90 hari) setelah tanggal laporan keuangan tahunan maka perusahaan dianggap tepat waktu sedangkan jika melebihi tanggal tersebut maka perusahaan dianggap tidak tepat waktu. Variabel ini diukur menggunakan variabel dummy, dengan kategori 1 bagi perusahaan yang memiliki ketepatan waktu (menyampaikan laporan keuangannya kurang dari 90 hari setelah akhir tahun atau sebelum tanggal 31 Maret) dan kategori 0 bagi perusahaan yang tidak tepat waktu (menyampaikan laporan keuangannya lebih dari 90 hari setelah akhir tahun atau setelah tanggal 31 Maret).

\section{Teknik Analisis Data}

1. Analisis Deskriptif

Data dalam penelitian ini dianalisis dengan statistik deskriptif. Statistik deskriptif memberikan gambaran tentang distribusi frekuensi variabel-variabel penelitian, nilai maksimum, minimum, rata-rata dan standar deviasi. 
2. Uji Hipotesis

Metode statistik yang digunakan untuk menguji hipotesis adalah regresi berganda binary dengan menggunakan logistik (logistic regression). Regresi berganda binary bertujuan untuk menguji pengaruh dengan data dependen adalah data kategorikal sedangkan data independennya adalah data kuantitatif (Sujarweni, 2007). Model logic berkaitan dengan fungsi probabilitas distribusi logistic (Widarjono, 2009). Model analisisnya adalah sebagai berikut:

$$
\begin{aligned}
& \operatorname{Ln} \frac{\mathrm{TL}}{1-\mathrm{TL}}=\alpha+\beta 1 \mathrm{ROA}+\beta 2 \mathrm{CR}+\beta 3 \log \mathrm{AA} \\
& \text { Keterangan: } \\
& \operatorname{Ln} \frac{\mathrm{TL}}{1-\mathrm{TL}}=\text { Ketepatan waktu penyampaian laporan keuangan (merupakan } \\
& \text { variabel dummy, kategori } 1 \text { untuk perusahaan yang tepat waktu } \\
& \text { dan } 0 \text { untuk perusahaan yang tidak tepat waktu) } \\
& \text { ROA }=\text { Return On Aset } \\
& \mathrm{CR} \quad=\text { Current Ratio } \\
& \log \mathrm{TA} \quad=\text { Total Asset yang dilogaritma kan } \\
& \alpha \quad=\text { Konstanta }
\end{aligned}
$$

Analisis pengujian dengan regresi logistik menurut memperhatikan hal-hal berikut:

a. Menilai kelayakan model regresi (Goodness of fit test).

Dengan memperhatikan output dari Hosmer dan Lemeshow dengan hipotesis:

$\mathrm{H} 0$ = Tidak ada perbedaan nyata antara klasifikasi yang diamati.

$\mathrm{Ha}=$ Ada perbedaan nyata antara klasifikasi yang diprediksi dengan klasifikasi yang diamati.

Dasar pengambilan keputusan yaitu dengan memperhatikan nilai I yang diukur dengan nilai chi-square pada bagian bawah uji Hosmer dan Lemeshow:
Jika probabilitas $>0,05 \mathrm{H} 0$ diterima Jika probabilitas < 0,05 H0 ditolak

b. Menilai keseluruhan model (Overall Model Fit)

Memperhatikan angka $-2 \log$ likelihood (LL) pada awal (block number $=0$ ) dan angka $-2 \log$ likelihood pada blocknumber $=1$. Jika terjadi penurunan angka -2 log likelihood block number 0block number 1 menunjukkan model regresi yang baik. Log likelihood pada regresi logistik mirip dengan pengertian "sum of squared error" pada model regresi, sehingga penurunan log likelihood menunjukkan model regresi yang baik.

c. Menguji koefisien regresi

Pengujian koefisien regresi dilakukan dengan memperhatikan beberapa hal berikut ini:

Tingkat signifikan $(\alpha)$ yang digunakan sebesar 5 persen $(0,05)$.

Kriteria penerimaan dan penolakan hipotesis didasarkan pada signifikansi p-value (probabilitas value).

Jika p-value (signifikasi) > $\alpha$, maka hipotesis alternatif ditolak.

Sebaliknya jika $\mathrm{p}$-value $<\alpha$, maka hipotesis alternatif diterima.

\section{HASIL PENELITIAN DAN PEMBAHASAN}

\section{Hasil Penelitian}

1. Hasil Analisis Deskriptif

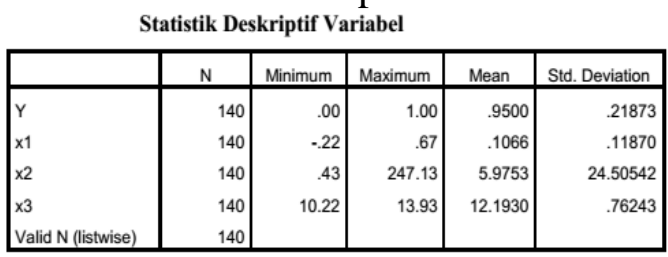

Data penelitian pada tabel di atas tersebut menunjukkan bentuk statistik deskriptif dari variabel-variabel yang digunakan dalam penelitian ini. Kondisi variabel X1 berupa ROA menunjukkan rata-rata sebesar 0,1066 
dengan standar deviasi sebesar 0,11870 serta nilai minimum $-0,22$ dan nilai maksimum 0,67. Rata-rata ROA perusahaan sampel memiliki nilai positif yang mengindikasikan bahwa perusahaan sampel memiliki kemampuan untuk menghasilkan laba. Kondisi variabel X2 yaitu variabel CR menunjukkan rata-rata sebesar 5,9753 dengan standar deviasi sebesar 24,50542 serta nilai minimum sebesar 0,43 dan nilai maksimum 247,13. Perusahaan sampel memiliki kemampuan untuk melunasi kewajiban jangka pendeknya dengan baik ditunjukkan dengan rata-ratanya yang positif. Kondisi variabel X2 (total asset) menunjukkan rata-rata sebesar 12,1930 dengan standar deviasi sebesar 0,76243 serta nilai minimum 10,22 dan nilai maksimum 13,93. Hal ini menunjukkan rata-rata perusahaan sampel memiliki total aset yang tidak terlalu jauh berbeda.

2. Hasil Uji Hipotesis

a. Menilai kelayakan model regresi

Hosmer and Lemeshow Test

\begin{tabular}{|c|c|c|c|}
\hline Step & Chi-square & df & Sig. \\
\hline 1 & 2.464 & 8 & .963 \\
\hline
\end{tabular}

Pada tabel tersebut terlihat bahwa besarnya nilai statistik Hosmer and Lemeshow Goodness of fit test sebesar 2,464 dengan probabilitas signifikansi 0,963 . Karena angka probabilitas > 0,05 maka H0 diterima. Hal ini berarti model regresi layak dipakai untuk analisa selanjutnya, karena tidak ada perbedaan yang nyata antara klasifikasi yang diprediksi dengan klasifikasi yang diamati. b. Menilai keseluruhan model Overall Model Fit Test

\begin{tabular}{|c|c|}
\hline Block Number $=0$ & Block Number $=1$ \\
-2 Log Likelihood & -2 Log Likelihood \\
\hline 55,584 & 43,221 \\
\hline
\end{tabular}

Pada tabel tersebut terlihat bahwa terjadi penurunan pada angka awal -2 LL Block Number $=0$ adalah 55,584 menjadi angka -2 LL Block Number $=1$ adalah 43,221. Terjadinya penurunan angka log likelihood ini menunjukkan model regresi baik.

c. Menguji koefisien regresi

Hasil Uji Koefisien Regresi Logistik

\begin{tabular}{|c|c|c|}
\hline & B & Sig. \\
\hline X1 & 14.560 & .017 \\
\hline$X 2$ & .130 & .598 \\
\hline$X 3$ & 1.063 & .070 \\
\hline Constant & -10.688 & .125 \\
\hline
\end{tabular}

Dari pengujian regresi logistik tersebut, maka diperoleh persamaan regresi logistik sebagai berikut:

$\mathrm{TL}=-10,688+14,560 \mathrm{ROA}+$ $0,130 \mathrm{CR}+1,063 \log \mathrm{TA}$

1) $\mathrm{H} 1=$ semakin tinggi profitabilitas maka semakin tinggi kemungkinan ketepatan waktu penyampaian laporan keuangan perusahaan manufaktur sektor industri barang konsumsi yang terdaftar di BEI. Variabel profitabilitas yang diukur dengan Return on Asset (ROA) menunjukkan nilai koefisien positif sebesar 14,560 dengan probabilitas variabel sebesar 0,017 di bawah tingkat signifikansi 0,05 (5 persen). Artinya dapat disimpulkan bahwa H1 diterima. Dengan demikian terbukti bahwa profitabilitas yang tinggi mampu meningkatkan kemungkinan ketepatan waktu pelaporan keuangan perusahaan.

2) $\mathrm{H} 2$ = semakin tinggi likuiditas maka semakin tinggi kemungkinan 
ketepatan waktu penyampaian laporan keuangan perusahaan manufaktur sektor industri barang konsumsi yang terdaftar di BEI.

Variabel likuiditas yang diukur dengan Current Asset (CR) menunjukkan nilai koefisien positif sebesar 0,130 dengan probabilitas 0,598 di atas tingkat signifikansi 0,05 yang berarti $\mathrm{H} 2$ ditolak, atau likuiditas yang semakin tinggi tidak mempengaruhi kemungkinan peningkatan ketepatan waktu pelaporan keuangan perusahaan.

$\mathrm{H} 3=$ semakin besar ukuran perusahaan maka semakin besar kemungkinan ketepatan waktu penyampaian laporan keuangan perusahaan manufaktur sektor industri barang konsumsi yang terdaftar di BEI. Variabel ukuran perusahaan yang diukur menggunakan Total Asset (TA) menunjukkan nilai koefisien positif sebesar 1,063 dengan probabilitas di atas signifikansi yaitu 0,070 yang berarti $\mathrm{H} 3$ ditolak, dengan kata lain ukuran perusahaan yang semakin besar tidak mempengaruhi kemungkinan peningkatan ketepatan waktu pelaporan keuangan perusahaan.

Model Summary

\begin{tabular}{|l|l|l|l|}
\hline Step & -2 Log likelihood & $\begin{array}{l}\text { Cox \& Snell } R \\
\text { Square }\end{array}$ & $\begin{array}{l}\text { Nagelkerke } \\
\text { Square }\end{array}$ \\
\hline 1 & $43.221^{\mathrm{a}}$ & .085 & 258 \\
\hline
\end{tabular}

menunjukkan bahwa penelitian ini melalui hasil output SPSS regresi logistic memberikan nilai Cox dan Snell's R sebesar 0,085 dan nilai Nagelkerke R2 sebesar 0,258. yang berarti variabilitas variabel dependen yang dapat dijelaskan oleh variabilitas variabel independen sebesar 25,8 persen.

\section{Pembahasan}

Berdasarkan pengujian regresi logistik yang telah dilakukan, didapatkan bahwa variabel profitabilitas yang diukur dengan return on asset (ROA) berpengaruh signifikan secara statistik pada tingkat kesalahan 5\%. Hal ini ditunjukkan dari hasil signifikansi 0,017 $<\quad 0,05$, sehingga H1 penelitian ini diterima. Pada tabel statistik deskriptif diperoleh hasil bahwa rata-rata perusahaan sampel mengalami keuntungan yaitu 0,1066. Meskipun perusahaan sampel rata-rata mengalami keuntungan cukup kecil tidak mempengaruhi perusahaan untuk tidak tepat waktu dalam menyampaikan laporan keuangannya. Hasil ini sesuai dengan penelitian yang dilakukan Dwiyanti (2010), bahwa profitabilitas berpengaruh terhadap ketepatan waktu pelaporan keuangan, karena para manajer sebagai agen ingin menunjukkan kinerja perusahaan yang sesuai dengan apa yang diinginkan oleh para prinsipal sehingga akan dipercaya untuk mengelola perusahaan untuk periode jangka panjang, disamping harapan adanya kompensasi berupa saham atau bonus kas atas kinerja mereka.

Variabel likuiditas yang di ukur menggunakan current ratio (CR) tidak berpengaruh signifikan secara statistik pada tingkat kesalahan 5\%. Hal ini ditunjukkan dari hasil signifikansi 0,598 $>0,05$, sehingga $\mathrm{H} 2$ dalam pelitian ini ditolak. Hal ini menunjukkan bahwa perusahaan dengan CR yang tinggi belum tentu diikuti dengan ketepatan waktu dalam menyampaikan laporan keuangannya, walaupun kemampuan perusahaan dalam melunasi kewajiban jangka pendek yang tinggi merupakan berita baik bagi perusahaan. Hasil penelitian ini sesuai dengan penelitian yang dilakukan oleh Permana (2009) yang menyatakan variabel likuiditas tidak berpengaruh terhadap ketepatan waktu penyampaian laporan keuangan perusahaan. 
Variabel ukuran perusahaan yang di ukur menggunakan total asset tidak berpengaruh signifikan secara statistik pada tingkat kesalahan 5\%. Hal ini ditunjukkan dari hasil signifikansi 0,070 $>0,05$, sehingga $\mathrm{H} 3$ dalam penelitian ini ditolak. Hal ini menunjukkan perusahaan dengan aset yang besar belum tentu akan berdampak pada kemampuan perusahaan dalam menyampaikan laporan keuangannya dengan tepat waktu. Hasil penelitian ini sesuai dengan penelitian yang dilakukan oleh Permana (2009) yang menyatakan ukuran perusahaan tidak berpengaruh secara signifikan terhadap ketepatan waktu penyampaian laporan keuangan.

\section{KESIMPULAN DAN SARAN}

\section{Kesimpulan}

1. Profitabilitas berpengaruh secara signifikan terhadap ketepatan waktu pelaporan keuangan.

2. Likuiditas tidak berpengaruh secara signifikan terhadap ketepatan waktu pelaporan keuangan.

3. Ukuran perusahaan tidak berpengaruh secara signifikan terhadap ketepatan waktu pelaporan keuangan.

\section{Saran}

1. Bagi peneliti selanjutnya, diharapkan dapat memasukkan variabel lain seperti leverage, opini auditor, kualitas auditor, kantor akuntan publik dan lain-lain, agar hasil penelitian lebih mampu untuk memprediksi ketepatan waktu pelaporan keuangan dengan lebih tepat.

2. Digunakan sampel yang berbeda, agar dapat melihat hasil dari sudut pandang yang lain.

3. Menambah tahun pengamatan sehingga hasil yang diperoleh lebih dapat dijadikan sebagai dasar prediksi ketepatan waktu pelaporan keuangan dan faktor-faktor yang mempengaruhinya.

4. Dilengkapi dengan uji asumsi klasik.

5. Manajemen perusahaan diharapkan mampu memperbaiki dan menerbitkan laporan keuangannya setiap tahunnya agar dapat digunakan sebagaimana mestinya oleh semua pengguna laporan keuangan.

6. Bagi investor, dalam mengambil keputusan tetap memperhatikan faktorfaktor lain di luar variabel penelitian ini seperti: leverage, kualitas auditor, kantor akuntan public, dan lainlain.

\section{DAFTAR PUSTAKA}

Asakdiyah, Salamatun. (2006). Manajemen Keuangan I Alat Analisis dan Aplikasi. UAD: Yogyakarta.

Evi, dkk. (2014). Pengaruh Profitabilitas dan Likuiditas terhadap Ketepatan Waktu Pelaporan Keuangan (Studi Empiris pada Perusahaan LQ45 yang terdaftar di BEI periode 2008-2012). e-Journal S1 Ak Universitas Pendidikan Ganesha. Vol. 02. No. 1. pp 1-10.

Harahap, Sofyan Syafri. (2007). Analisis Kritis atas Laporan Keuangan. Jakarta: Raja Grafindo

Hilmi, Utari. dan Ali, Syaiful. (2008). Analisis Faktor-Faktor yang Mempengaruhi Ketepatan Waktu Penyampaian Laporan Keuangan. Simposium Nasional Akuntansi XI Ikatan Akuntan Indonesia. h.1-22.

Ikatan Akuntan Indonesia. (2009). Standar Akuntansi Keuangan. Jakarta: Salemba Empat. 
Nasution, Khiyanda Alfian. (2009). Pengaruh Likuiditas, Ukuran Perusahaan dan Profitabilitas terhadap Ketepatan Waktu dalam Pelaporan Keuangan. Skripsi. Padang

Owusu-Ansah, Stephen. (2000). Timeliness of Corporate Financial Reporting in Emerging Capital Market: Empirical Evidence from The Zimbabwe Stock Exchange. Journal Accounting and Business Research. Vol.30. No.3. pp.241-254.

Permana, Syaikhul. (2009). Pengaruh Profitabilitas, Leverage, Likuiditas, dan Ukuran Perusahaan terhadap Ketepatan Waktu Penyampaian Laporan Keuangan Perusahaan Properti yang terdaftar di BEI. Skripsi. Semarang

Sudarmadji, A. M. dan Lana Sularto, (2007). Pengaruh Ukuran Perusahaan, Profitabilitas, Leverage dan Tipe Kepemilikan Perusahaan Terhadap Luas Voluntary Disclosure Laporan keuangan Tahunan. Jurnal PESAT (Psikologi, Ekonomi, Sastra, Arsitek \& Sipil), Volume 2, Universitas Gunadarma Jakarta.

Sugiyono. (2013). Metodologi Penelitian Pendidikan (Pendekatan Kuantitatif, Kualitatif, $\quad R \& D)$. Bandung: Alfabeta.

Sujarweni, V. Wiratna. (2007). Belajar Mudah SPSS Untuk Penelitian Skripsi, Tesis, Disertasi, dan Umum. Yogyakarta: Ardana Media.

Suwito, Edy dan Herawaty, Arleen. (2005). Reaktualisasi Pendidikan dan Penelitian Akuntansi Dalam Meningkatkan Peran Profesi Akuntansi Di Era Global. Simposium Nasional Akuntansi VIII.
Widarjono, Agus. (2009). Ekonometrika Pengantar dan Aplikasinya. Yogyakarta: Ekonisia.

Yadiati, Winwin. (2007). Teori Akuntansi - Suatu Pengantar. Jakarta: Kencana 